\title{
Future Teachers' Smartphone Uses and Dependence
}

\author{
Julio Ruiz-Palmero ${ }^{1, *} * \mathbb{D}$, Enrique Sánchez-Rivas ${ }^{1}$, Melchor Gómez-García ${ }^{2}$ and \\ Elena Sánchez Vega ${ }^{3}$ \\ 1 Faculty of Education Sciences, University of Málaga, Bulevar Louis Pasteur, 25, 29071 Málaga, Spain \\ 2 Faculty of Teaching Training and Education, Autonomous University of Madrid, \\ Carretera de Colmenar Viejo, Km. 15,500, 28049 Madrid, Spain \\ 3 Centro Abanza. Av. Leo Delibes, 4, 29004 Málaga, Spain \\ * Correspondence: julio@uma.es
}

Received: 2 June 2019; Accepted: 22 July 2019; Published: 23 July 2019

\begin{abstract}
Smartphones are indeed becoming an essential tool in the daily lives and relations of their users in recent years, thanks to their uses and potential. However, excessive and inappropriate use can lead to dependence syndromes. The objectives of our study were to ascertain how these devices are being used and whether students are at risk of addiction. The study was carried out based on a survey with students-future teachers-from two Spanish universities. A sample of 453 students between the ages of 18 and 47 was analyzed, $76.8 \%$ female and $23.2 \%$ male. Smartphones were found to be the preferred Internet connection device for $80 \%$ of students, $38 \%$ of students connect to the Internet five hours or more a day (which can be considered an addiction) and smartphones are used primarily to connect with others (social media and instant messaging). The abusive use of smartphones affects men's behavior more than women and can lead them to neglect other activities, while smartphones affect women more in the emotional field, in matters related to boredom, impatience, and irritability.
\end{abstract}

Keywords: smartphone usage; smartphone addiction; higher education; mobile digital devices; gender

\section{Introduction}

In the past years, the number of active mobile lines has rocketed to the point of exceeding the world's current population for the first time [1]. Having said that, there are significant differences between regions. Central and Eastern Europe (151\%), Western Europe (129\%) and South America $(124 \%)$ have the highest penetration [2]. In Western countries, mobile telephone lines reach penetration rates close to $100 \%$ of the population. In Spain, specifically, there were 110.9 lines per 100 inhabitants in 2017 [3].

These figures explain the fact that smartphones are used every day by a large part of society and that they have changed the way we work and relate to each other, becoming increasingly indispensable instruments. Studies indicate that $92.8 \%$ of Spaniards use a smartphone every day to access the Internet [4], a percentage that rises to $99 \%$ in the case of young people. Sixty-one percent admit to checking their phones within the first five minutes after waking up, in the US, this percentage is $46 \%$ [5], but it increases to $66 \%$ if we look at young people between 18 and 24 years.

\section{Literature Review}

The use of smartphones has become a core part of university students' lives. They use smartphones in their academic activity to exchange information, coordinate group work, and consult services [6] and, in their daily life, to communicate, manage information, entertain themselves, play games, etc. $[4,7]$. This phenomenon is favored by the increasingly prominent features of this type of device: Touch 
screens, Internet access, the possibility of installing all kinds of applications, digital cameras, GPS navigation, etc.

The vast potential of smartphones is coupled with their ability to multitask-understood as doing more than one thing at a time [8]—especially for students, as they are often connected to social media or chatting with friends while studying or working on academic activities. This situation adversely influences effective learning, as it is a major source of distraction [9] and can lead to poor academic performance.

Unsurprisingly, the use of computers decreases, giving way to the use of mobile devices such as tablets or smartphones [10]. 94.6\% of Spaniards [4] use the smartphone to access the Internet, and this generates various problems: Physical pain in the neck [11,12], sleep disorders [13] or road traffic accidents affecting pedestrians and/or drivers [14-16]. Figures prompt reflection, such as the fact that between 2011 and 2017, 259 people died when doing a selfie [17]. On top of this, we have the problematic use [18] of these devices, understood as the compulsive use that leads to a disorder and deterioration of social relations, physical health, emotional well-being, or academic or work performance [19-22].

As for the educational use of smartphones, education is still held up in a "parallel" process in which these technological resources have not yet been analyzed, understood, or even included. Therefore, we find that some educational institutions are considering banning them completely in classrooms but others, on the other hand, welcome them and include them as another resource. Some studies say that the ban increases student achievement and that, because such increases are higher in students with lower levels, the smartphone ban can help reduce educational inequalities [23]. However, some experts say that smartphones should not be thought of as an object of distraction but as elements bearing education potential. If used in the latter way, a positive relationship could be found in students' learning outcomes [24].

Regardless of this controversy, educational institutions, in today's world, must tend to develop the capabilities that are demanded of individuals: Flexibility, connectivity, team player, etc. Therefore, this field still requires of further studies to analyze the use of devices, such as smartphones, in future teachers and ascertain whether they represent a problem in the activity and relationships of those who use them.

The objectives, therefore, of our study with future teachers were:

1. Ascertain their use of the Internet.

2. Find out about smartphone applications.

3. Determine whether students presented a problematic use of smartphones.

4. Analyze whether the gender variable is influential or not.

\section{Material and Methods}

\subsection{Population and Sampling}

We undertook a comparative, non-experimental study of Internet use and smartphone dependence in the university context.

An incidental accessibility sampling was carried out among university students of Education Sciences corresponding to two Spanish universities (Table 1), for them to complete a questionnaire. The participants made up a sample of 453 students, after having discarded 65 incomplete questionnaires.

Table 1. Universities and participants.

\begin{tabular}{cc}
\hline University & Participants \\
\hline Malaga University & 258 \\
Autonomous University of Madrid & 195 \\
\hline
\end{tabular}


Of these, 105 were men $(23.2 \%)$ and 348 women $(76.8 \%)$, all between the ages of 18 and 47 $(\mathrm{M}=20.67, \mathrm{SD}=4.89)$.

\subsection{Instruments}

A questionnaire was prepared for electronic and anonymous completion by the students to collect information. The data collection was carried out between February and May 2018. The students were duly informed, and their consent to participate in the questionnaire was sought beforehand in class. The link to the questionnaire was sent to them by email.

The questionnaire was made up of a total of 74 items divided into several sections:

1. Personal and connection data (university, gender, age, daily Internet connection time, device and place of connection). We relied on the items of Vega et al. for this section [25].

2. Use of the smartphone. We asked about the frequency of use of 11 types of functions, as proposed by Elhai et al. [26]: "Making and receiving voice and/or video calls", "Sending and receiving instant text messages", "Sending and receiving emails", "Using social media sites", "Surfing the Internet/Websites", "Playing games", "Listening to music/podcasts/radio", "Taking pictures and/or videos", "Watching videos/TV/movies", "Reading books/magazines/newspapers", "Viewing maps/navigation".

3. Problematic use of smartphones. We used the smartphone addiction scale (SAS) by Kwon et al. [27], which consists of 48 elements.

For Sections 2 and 3, we used a six-point Likert scale from $1=$ Never to $6=$ Very often. The Cronbach alpha was applied to both, which yielded values of 0.942 for both.

\subsection{Data Analysis}

The data were analysed using SPSS v.20, which calculated the frequency and percentage of the variables regarding Internet use. A bivariate analysis was carried out using the $\chi^{2}$ test between these and the gender variable. The mean and standard deviation were calculated for the use of smartphones. Finally, a factorial analysis was carried out for smartphone addiction items.

\section{Results}

The findings obtained in the research are presented in the following sections.

\subsection{Internet Usage}

In response to our first objective, which was to describe Internet usage, we analyzed the percentages of each of the items. The data obtained indicate that a large part of the student body is quite connected: $82.1 \%$ more than three hours a day $(n=372), 38.4 \%(n=174)$ more than five hours (Table 2$)$.

Table 2. Connection hours per day.

\begin{tabular}{ccccc}
\hline & \multicolumn{2}{c}{ Gender } & Total & Percentage \\
\cline { 2 - 3 } & Female & Male & & \\
\hline Less than 1 $\mathrm{h}$ & 0 & 3 & 3 & $0.7 \%$ \\
From 1 to 2 $\mathrm{h}$ & 33 & 3 & 36 & $7.9 \%$ \\
From 2 to 3 $\mathrm{h}$ & 39 & 3 & 42 & $9.3 \%$ \\
From 3 to 4 $\mathrm{h}$ & 78 & 27 & 105 & $23.2 \%$ \\
From 4 to 5 $\mathrm{h}$ & 75 & 18 & 93 & $20.5 \%$ \\
More than 5 $\mathrm{h}$ & 123 & 51 & 174 & $38.4 \%$ \\
$\quad$ Total & 348 & 105 & 453 & $100 \%$ \\
\hline
\end{tabular}

Significant differences are seen for gender and hours of connection per day $\left(\chi^{2}(5, N=453)=0.000\right.$, $p<0.005)$, where women are seen to connect to the Internet for a higher number of hours than men. 
To find out the incidence of the use of smartphones as a device to connect to the Internet, we asked students what means they used (Table 3). The most widely used is the smartphone (94.7\%) followed by the netbook $(68.9 \%)$.

Table 3. Internet connection device.

\begin{tabular}{cccccc}
\hline & \multicolumn{2}{c}{ Gender } & & Total & Percentage \\
\cline { 2 - 3 } & Female & Male & & \\
\hline Netbook & 225 & 9 & 303 & $68.9 \%$ \\
Tablet & 39 & 9 & 48 & $10.6 \%$ \\
Smartphone & 342 & 87 & & 429 & $94.7 \%$ \\
Personal computer & 4 & 2 & 6 & $1.3 \%$ \\
TV/Console & 3 & 3 & 6 & $1.3 \%$ \\
\hline
\end{tabular}

There are no significant differences regarding gender and connection device for netbooks and tablets, but there are in the use of smartphones $\left(\chi^{2}(1, N=453)=0.000, p<0.005\right)$, where a higher percentage of women (98.3\%) use this device to connect to the Internet compared to men $(82.9 \%)$.

Concerning where and how often they use the smartphone, a Likert scale with five points was used: $1=$ Never, 2 = A few days a month, $3=$ a few days a week, $4=$ almost every day, and $5=$ daily (Table 4).

Table 4. Where and how often you use your smartphone.

\begin{tabular}{|c|c|c|c|c|c|c|c|c|c|c|}
\hline & \multicolumn{10}{|c|}{ Gender } \\
\hline & 1 & 2 & 3 & 4 & 5 & 1 & 2 & 3 & 4 & 5 \\
\hline \multirow{2}{*}{ At home } & & & 6 & 15 & 327 & & & & 9 & 96 \\
\hline & & & $1.7 \%$ & $4.3 \%$ & $94 \%$ & & & & $8.6 \%$ & $91.4 \%$ \\
\hline \multirow{2}{*}{ While I move } & 21 & 27 & 54 & 72 & 174 & 12 & 9 & 12 & 18 & 54 \\
\hline & $6 \%$ & $7.8 \%$ & $15.5 \%$ & $20.7 \%$ & $50 \%$ & $11.4 \%$ & $8.6 \%$ & $11.4 \%$ & $17.1 \%$ & $51.4 \%$ \\
\hline \multirow{2}{*}{ On the street } & 18 & 15 & 60 & 108 & 147 & 6 & 6 & 12 & 30 & 51 \\
\hline & $5.2 \%$ & $4.3 \%$ & $17.2 \%$ & $31 \%$ & $42.2 \%$ & $5.7 \%$ & $5.7 \%$ & $11.4 \%$ & $28.6 \%$ & $48.6 \%$ \\
\hline
\end{tabular}

There are no significant differences between gender and place of connection in any of the cases. The place where the smartphone is most used on a daily basis is the place of residence for both men and women (92.7\% on a daily basis), the university ( $81.8 \%$ almost every day or daily) and means of transport (69.6\% practically every day or daily).

\subsection{Smartphone Applications}

A Likert scale with 6 points was used to determine the frequency of use of the following phone functions: 1 = Never, $2=$ Rarely, $3=$ Occasionally, $4=$ Somewhat often, $5=$ Often and $6=$ Very often. Table 5 shows that the most frequent uses are social media, instant messaging, Internet browsing and listening to music/podcast/radio. The least frequent uses are to play games, read (books, magazines, newspapers) and consult maps. 
Table 5. Smartphone functions.

\begin{tabular}{ccc}
\hline Functions & Average & Standard Deviation \\
\hline Make and receive voice and/or video calls & 3.61 & 1.293 \\
Send and receive instant text messages & 5.34 & 1.262 \\
Send and receive emails & 4.26 & 1.137 \\
Use social media sites & 5.35 & 1.070 \\
Surfing the Internet/Websites & 4.92 & 1.047 \\
Play games & 2.78 & 1.372 \\
Listen to music/podcasts/radio & 4.72 & 1.360 \\
Take pictures and/or videos & 4.27 & 1.457 \\
Watch videos/TV/movies & 4.38 & 1.461 \\
Read books/magazines/newspapers & 3.40 & 1.278 \\
Consult maps/navigation & 3.40 & 1.142 \\
\hline
\end{tabular}

There are no significant differences between gender and phone functions in any of the cases.

\subsection{Problematic Use of Smartphones}

For the 48 items that make up the SAS of Kwon et al. [27], a factorial analysis was used, in particular, the rotation technique because it is assumed that they are correlated with each other, therefore, they are not independent.

For the anti-image analysis, variable 27 was eliminated, as it had the lowest correlation value. Using Bartlett's spherical contrast $\left(\chi^{2}(\mathrm{gl}=1081, N=453)=14,785.035, p=0.000\right)$, there are grounds to say that they correlate in the subjects studied, so the correlation matrix is suitable for factorisation. The Kaiser-Meyer-Olkin sample adequacy measure $(\mathrm{KMO}=0.901)$ also indicated that the correlation matrix was suitable for analysis.

A non-excessive number of factors is essential to achieve a clear factor structure. In this case and due to a large number of variables, if the analysis of the main components with Varimax rotation with Kaiser is used as an extraction method, it would result in 10 components with values greater than one. If the Cattell Scree test [28] procedure is chosen, which uses the sedimentation graph to see in which factor a clear inflection in the descending line is observed, we would have three factors. The latter method does not explain a large percentage of the variance. An intermediate solution considering six factors, which explained $57.074 \%$ of the variance (Table 6), was chosen in the end.

The rotated component matrix was used to check which items made up each of the factors. Table 7 shows the labels used for each one, the items that compose them and a brief explanation of them.

The first explained $35.35 \%$ of the variance and consisted of items $45,46,5,47,4,44,8,2,3,34$, and 48 of the questionnaire. Considering its content, this first factor was labeled as excessive use and physical consequences, as they refer to overuse and its physical implications.

The second factor, composed of eight items $(21,23,19,20,25,26,15$, and 28), explained $6.8 \%$ of the variance. It was labeled as emotional consequences when grouping items in which irritability, impatience, depression, and stress were manifested when using a smartphone or experiencing the impossibility of doing so.

The third factor explained $4.18 \%$ of the variance and consisted of items $18,14,7,38,6,39,17,16$, and 9. They refer to attributing fun or tolerance to smartphone use or inability to perform tasks and duties due to excessive use. This factor was labeled as feelings and non-compliances.

Items 10,11,12,13, and 30 make up the fourth factor, labelled as safety/wellness, by attributing safety or well-being to the use of the smartphone. They explain $3.92 \%$ of the variance.

The fifth factor, labelled as the physical proximity of the device, is comprised of items $24,40,35,41$, 29,43 , and 42 and explained $3.55 \%$ of the variance. They encompass the need to have the smartphone physically close by and use it repeatedly. 
Table 6. Total variance explained.

\begin{tabular}{|c|c|c|c|c|c|c|c|c|c|}
\hline \multirow[t]{2}{*}{ Component } & \multicolumn{3}{|c|}{ Initial Self-Values } & \multicolumn{3}{|c|}{$\begin{array}{l}\text { Sum of the Extraction } \\
\text { Saturations Squared }\end{array}$} & \multicolumn{3}{|c|}{$\begin{array}{l}\text { Sum of the Rotation } \\
\text { Saturations Squared }\end{array}$} \\
\hline & Total & $\begin{array}{c}\% \text { of } \\
\text { variance }\end{array}$ & $\begin{array}{c}\% \\
\text { cumulative }\end{array}$ & Total & $\begin{array}{c}\% \text { of } \\
\text { variance }\end{array}$ & $\begin{array}{c}\% \\
\text { cumulative }\end{array}$ & Total & $\begin{array}{c}\% \text { of } \\
\text { variance }\end{array}$ & $\begin{array}{c}\% \\
\text { cumulative }\end{array}$ \\
\hline 1 & 16,615 & 35,351 & 35,351 & 16,615 & 35,351 & 35,351 & 5,786 & 12,312 & 12,312 \\
\hline 2 & 3200 & 6809 & 42,160 & 3200 & 6809 & 42,160 & 5749 & 12,233 & 24,544 \\
\hline 3 & 1967 & 4185 & 46,345 & 1967 & 4185 & 46,345 & 4523 & 9623 & 34,167 \\
\hline 4 & 1846 & 3928 & 50,274 & 1846 & 3928 & 50,274 & 3671 & 7810 & 41,977 \\
\hline 5 & 1672 & 3557 & 53,831 & 1672 & 3557 & 53,831 & 3602 & 7664 & 49,641 \\
\hline 6 & 1524 & 3243 & 57,074 & 1524 & 3243 & 57,074 & 3493 & 7433 & 57,074 \\
\hline 7 & 1461 & 3109 & 60,182 & & & & & & \\
\hline 8 & 1366 & 2906 & 63,088 & & & & & & \\
\hline 9 & 1132 & 2409 & 65,496 & & & & & & \\
\hline 10 & 1120 & 2383 & 67,879 & & & & & & \\
\hline 11 & 991 & 2108 & 69,987 & & & & & & \\
\hline 12 & 934 & 1988 & 71,975 & & & & & & \\
\hline 13 & 881 & 1876 & 73,850 & & & & & & \\
\hline 14 & 813 & 1729 & 75,580 & & & & & & \\
\hline 15 & 738 & 1570 & 77,150 & & & & & & \\
\hline 16 & 714 & 1520 & 78,670 & & & & & & \\
\hline 17 & 694 & 1476 & 80,146 & & & & & & \\
\hline 18 & 650 & 1382 & 81,528 & & & & & & \\
\hline 19 & 638 & 1358 & 82,886 & & & & & & \\
\hline 20 & 551 & 1173 & 84,059 & & & & & & \\
\hline 21 & 528 & 1124 & 85,183 & & & & & & \\
\hline 22 & 523 & 1112 & 86,295 & & & & & & \\
\hline 23 & 482 & 1025 & 87,320 & & & & & & \\
\hline 24 & 465 & 990 & 88,310 & & & & & & \\
\hline 25 & 428 & 911 & 89,221 & & & & & & \\
\hline 26 & 397 & 846 & 90,066 & & & & & & \\
\hline 27 & 386 & 821 & 90,887 & & & & & & \\
\hline 28 & 381 & 810 & 91,697 & & & & & & \\
\hline 29 & 364 & 775 & 92,472 & & & & & & \\
\hline 30 & 327 & 695 & 93,167 & & & & & & \\
\hline 31 & 316 & 671 & 93,838 & & & & & & \\
\hline 32 & 299 & 637 & 94,475 & & & & & & \\
\hline 33 & 277 & 588 & 95,063 & & & & & & \\
\hline 34 & 245 & 522 & 95,585 & & & & & & \\
\hline 35 & 233 & 496 & 96,081 & & & & & & \\
\hline 36 & 231 & 492 & 96,573 & & & & & & \\
\hline 37 & 215 & 457 & 97,030 & & & & & & \\
\hline 38 & 194 & 413 & 97,443 & & & & & & \\
\hline 39 & 187 & 399 & 97,842 & & & & & & \\
\hline 40 & 176 & 373 & 98,215 & & & & & & \\
\hline 41 & 163 & 346 & 98,561 & & & & & & \\
\hline 42 & 140 & 298 & 98,860 & & & & & & \\
\hline 43 & 129 & 275 & 99,135 & & & & & & \\
\hline 44 & 119 & 252 & 99,387 & & & & & & \\
\hline 45 & 115 & 244 & 99,631 & & & & & & \\
\hline 46 & 93 & 198 & 99,829 & & & & & & \\
\hline 47 & 81 & 171 & 100,000 & & & & & & \\
\hline
\end{tabular}

Finally, the sixth factor explained $3.24 \%$ of the variance and consisted of items, 33, 37, 36, 32, 31, 1 , and 22. They refer to the difficulty of curbing the use of telephones and the family problems they entail.

Concerning gender, there are significant differences in factors 2 and 3 (see Table 8: ANOVA one-way analysis of variance). 
Table 7. Factors.

\begin{tabular}{|c|c|c|c|}
\hline Component & Variance & Items Forming It & Description \\
\hline $\begin{array}{l}\text { 1. Excessive use } \\
\text { and physical } \\
\text { consequences }\end{array}$ & 35.351 & $\begin{array}{c}45,46,5,47,4,44,8,2 \\
3,34,48\end{array}$ & $\begin{array}{l}\text { I've tried over and over again to shorten the time I } \\
\text { use my phone, but I don't seem to manage it } \\
\text { I always think I should shorten the time I use my } \\
\text { phone for } \\
\text { I feel tired and sleepless due to excessive phone use } \\
\text { The people around me tell me that I use my phone } \\
\text { too much } \\
\text { I feel pain in my wrists or behind my neck while } \\
\text { using the phone } \\
\text { I feel the need to use my phone again after I stop } \\
\text { using it } \\
\text { I have family conflicts due to my use of the } \\
\text { telephone } \\
\text { I have trouble concentrating in class, while doing } \\
\text { homework or while working due to telephone use } \\
\text { I experience dizziness or blurred vision due to } \\
\text { excessive telephone use } \\
\text { I constantly check my phone, so I don't miss } \\
\text { conversations between other people on Twitter, } \\
\text { Facebook, WhatsApp ... } \\
\text { I prefer web browsing on my phone to doing it on } \\
\text { computers }\end{array}$ \\
\hline $\begin{array}{l}\text { 2. Emotional } \\
\text { Consequences }\end{array}$ & 6.809 & $\begin{array}{c}21,23,19,20,25,26 \\
15,28\end{array}$ & $\begin{array}{l}\text { I think about my phone even when I'm not using it } \\
\text { I get irritated when people bother me while I'm } \\
\text { using my phone } \\
\text { I can't be without a phone } \\
\text { I feel impatient and upset when I'm not using my } \\
\text { phone } \\
\text { I feel depressed, anxious, or hypersensitive when I } \\
\text { can't use my phone } \\
\text { I feel stressed when I'm not in a Wi-Fi area or don't } \\
\text { have data } \\
\text { I have used the phone just to feel good } \\
\text { I feel bored while doing other things without my } \\
\text { phone }\end{array}$ \\
\hline $\begin{array}{l}\text { 3. Feelings and } \\
\text { breaches }\end{array}$ & 4.185 & $\begin{array}{c}18,14,7,38,6,39,17 \\
16,9\end{array}$ & $\begin{array}{l}\text { Using a phone is the most entertaining thing you } \\
\text { can do } \\
\text { There's nothing more fun to do in my life than to } \\
\text { use the phone } \\
\text { Due to the use of the phone, I neglect other matters, } \\
\text { even when there are many other things to do } \\
\text { I try to hide what I've been doing with my phone } \\
\text { I feel unable to do anything without a phone, such } \\
\text { as timetables and personal matters that I keep on } \\
\text { the phone } \\
\text { I can't keep my appointments due to excessive } \\
\text { phone use } \\
\text { I feel more tolerant while using a phone } \\
\text { My life would be empty without my phone } \\
\text { I experience auditory hallucinations of telephone } \\
\text { sounds while I am not using it }\end{array}$ \\
\hline $\begin{array}{c}4 . \\
\text { Safety/well-being }\end{array}$ & 3.928 & $10,11,12,13,30$ & $\begin{array}{l}\text { I feel at peace or calm while using the phone } \\
\text { I feel good or excited while using the phone } \\
\text { I feel safe while using the phone } \\
\text { I am able to get rid of stress by using the phone } \\
\text { I feel great meeting people over the phone }\end{array}$ \\
\hline
\end{tabular}


Table 7. Cont.

\begin{tabular}{|c|c|c|c|}
\hline Component & Variance & Items Forming It & Description \\
\hline $\begin{array}{l}\text { 5. Physical } \\
\text { proximity of the } \\
\text { device }\end{array}$ & 3.557 & $\begin{array}{c}24,40,35,41,29 \\
43,42\end{array}$ & $\begin{array}{l}\text { I take my phone to the bathroom, even when I'm in } \\
\text { a hurry to get there } \\
\text { I have used my phone when I shouldn't (in class, } \\
\text { during a meeting, etc.) } \\
\text { I check social media feeds like Twitter, Facebook or } \\
\text { WhatsApp as soon as I wake up } \\
\text { I'd rather search with my phone than ask } \\
\text { other people } \\
\text { I feel relieved with my phone next to my bed when } \\
\text { I go to sleep } \\
\text { I use my phone for longer than I expected } \\
\text { My fully charged battery doesn't last an entire day }\end{array}$ \\
\hline 6. Relationships & 3.243 & $33,37,36,32,31,1,22$ & $\begin{array}{l}\text { I feel that my "phone" friends understand me } \\
\text { better than my real-life friends } \\
\text { I don't mind spending money on phone apps } \\
\text { I'd rather hang out talking with my friends on the } \\
\text { phone than with real-life friends or other family } \\
\text { members } \\
\text { Not being able to use my phone would be as } \\
\text { painful as losing a friend } \\
\text { I feel that my relationships with my friends over } \\
\text { the phone are more intimate than my relationships } \\
\text { with my real-life friends } \\
\text { I miss/do not go to scheduled work events due to } \\
\text { telephone use } \\
\text { I will never give up using my phone, even though } \\
\text { my daily life has already been greatly affected by it }\end{array}$ \\
\hline
\end{tabular}

Table 8. Differences according to gender.

\begin{tabular}{|c|c|c|c|c|c|}
\hline & Gender & Average & $\begin{array}{l}\text { Standard } \\
\text { Deviation }\end{array}$ & $\mathbf{F}$ & $p$ \\
\hline \multirow{2}{*}{$\begin{array}{l}\text { 1. Excessive use and physical } \\
\text { consequences }\end{array}$} & Female & -0.021 & 0.95 & \multirow{2}{*}{0.719} & \multirow{2}{*}{0.397} \\
\hline & Male & 0.072 & 1.13 & & \\
\hline \multirow{2}{*}{ 2. Emotional Consequences } & Female & 0.093 & 0.98 & \multirow{2}{*}{13.517} & \multirow{2}{*}{0.000} \\
\hline & Male & -0.31 & 0.97 & & \\
\hline \multirow{2}{*}{ 3. Feelings and breaches } & Female & -0.13 & 0.90 & \multirow{2}{*}{31.346} & \multirow{2}{*}{0.000} \\
\hline & Male & 0.46 & 1.16 & & \\
\hline \multirow{2}{*}{ 4. Safety/well-being } & Female & 0.01 & 0.98 & \multirow{2}{*}{0.585} & \multirow{2}{*}{0.445} \\
\hline & Male & -0.06 & 1.04 & & \\
\hline \multirow{2}{*}{ 5. Physical proximity of the device } & Female & 0.014 & 1.00 & \multirow{2}{*}{0.297} & \multirow{2}{*}{0.586} \\
\hline & Male & -0.04 & 0.98 & & \\
\hline \multirow{2}{*}{ 6. Relationships } & Female & -0.05 & 1.02 & \multirow{2}{*}{4.026} & \multirow{2}{*}{0.045} \\
\hline & Male & 0.17 & 0.88 & & \\
\hline
\end{tabular}

\section{Discussion}

Internet access has undoubtedly become a core part of our daily lives regardless of our age, whether we are at home, work or school, and for all purposes such as leisure, communication, information, etc.

This phenomenon has become all the more visible in teenagers and young adults. It is a fact that is generating a social alarm, to the extent of becoming labelled as an addiction if used excessive and inappropriately. Some authors have set the limit of such addiction at about $30 \mathrm{~h}$ a week [29]. Bearing in mind that $38.4 \%$ of our students spend $35 \mathrm{~h}$ a week (five or more hours a day) connected 
to the Internet (in line with other studies [30-33]), we could safely say that they have addiction problems and that they may be prone to developing adverse symptoms at physiological, cognitive and behavioral [34-37] levels.

As far as gender is concerned, men spend more time connected to the Internet than women, along the lines of other studies [25].

As for the device used to connect to the Internet, the preferred one by more than $80 \%$ is the smartphone $[25,38,39]$, where more women $(98.3 \%)$ use it compared to men $(82.9 \%)$, followed by the netbook.

The most commonplace of daily connection is people's homes $(92.7 \%)$ and university $(51 \%)$, followed by means of transport (50.7\%) [32,40].

The most frequent uses of the smartphone are: Connecting with others (social media and instant messaging) [32,41,42], searching for information and listening to music. The least frequent are: Games and reading. It is precisely the multiple activities that can be carried out at the same time, that feed two types of needs (social interaction and solitary stimulation), that in turn, feeds the addiction to the Internet. Eighty-five percent of students say they use instant messaging often or very often and $83 \%$ use social media and highlight their need to keep in constant contact with their peers $[31,43,44]$.

When it comes to problematic smartphone use, women, on the one hand, are more emotionally involved than men (they cannot be without the smartphone, they think about it, get impatient, get bored and depressed when they do not use it, they feel good about using it and get irritated if bothered). On the other hand, more and more men consider the use of smartphones as the most fun and entertaining activity, without which their life would be empty, to the point of neglecting other issues and missing appointments and feeling unable to do anything without their smartphone, because of their dependence on the device. They would even try to hide what they have been doing with the phone and experience auditory hallucinations of phone sounds while they are not using it [45].

\section{Limitations of the Present Study}

Regarding the limitations of the study, first, the restrictions of transversal research should be highlighted, such as the difficulty of clearly establishing cause and effect relationships. Secondly, there were sampling issues because the sample is small and comes from two universities, which makes any generalization of results somewhat challenging. It would, therefore, be advisable to continue with longitudinal studies, of larger samples and using other forms of measurement beyond self-reporting.

\section{Conclusions}

The use of mobile phones by future teachers makes it clear that we are facing a reality to which we have to respond from the faculties of education. Offering good practices and appropriate training to the learning environments in which they will work in the future.

Author Contributions: Conceptualization, J.R.-P.; Data curation, J.R.-P.; Investigation, J.R.-P.; Methodology, E.S.-R.; Resources, M.G.-G. and E.S.V.; Validation, M.G.-G. and E.S.V.; Writing-original draft, E.S.-R.; Writing-review \& editing, M.G.-G.

Funding: This research received no external funding.

Conflicts of Interest: The authors declare no conflict of interest.

\section{References}

1. Muñoz, R. El Número de Líneas Móviles Supera Por Primera Vez A La Población Mundial. Available online: https://elpais.com/tecnologia/2018/02/27/actualidad/1519725291_071783.html (accessed on 5 October 2018).

2. Ditrendia. Ditrendia Informe Mobile en España y el mundo 2014; Ditrendia: Madrid, Spain, 2014; Available online: https://ditrendia.es/informe-ditrendia-mobile-en-espana-y-el-mundo/ (accessed on 25 October 2018). 
3. Comisión Nacional de Los Mercados y la Competencia. CNMC Informe Económico Sectorial de Las Telecomunicaciones y el Audiovisual; Comisión Nacional de los Mercados y la Competencia: Madrid, Spain, 2017; Available online: https://ditrendia.es/informe-mobile-espana-mundo-2017/ (accessed on 3 October 2018).

4. Ditrendia. Ditrendia Informe Mobile en España y en el Mundo 2017; Ditrendia: Madrid, Spain, 2017; Available online: https://ditrendia.es/informe-mobile-espana-mundo-2017/ (accessed on 13 October 2018).

5. ReportLinker. U.S. Smartphone Users Statistics in 2017: A Round-the-Clock Connection; Reportlinker Insight: Paris, France, 2017.

6. Vázquez-Cano, E.; Sevillano García, L. El smartphone en la educación superior. Un estudio comparativo del uso educativo, social y ubicuo en universidades españolas e hispanoamericanas. Signo Pensam. 2015, 34, 114. [CrossRef]

7. Organista-Sandoval, J.; Serrano-Santoyo, A.; McAnally-Salas, L.; Lavigne, G. Apropiación y usos educativos del celular por estudiantes y docentes universitarios. Rev. Electrón. Investig. Educ. 2013, 15, 139-156.

8. Wood, E.; Zivcakova, L.; Gentile, P.; Archer, K.; De Pasquale, D.; Nosko, A. Examining the impact of off-task multi-tasking with technology on real-time classroom learning. Comput. Educ. 2012, 58, 365-374. [CrossRef]

9. Chen, Q.; Yan, Z. Does multitasking with mobile phones affect learning? A review. Comput. Hum. Behav. 2016, 54, 34-42. [CrossRef]

10. Chaffey, D. Mobile Marketing Statistics Compilation. Available online: http:/www.smartinsights.com/ mobile-marketing/mobile-marketing-analytics/mobile-marketing-statistics/ (accessed on 16 November 2018).

11. Lee, S.; Choi, Y.H.; Kim, J. Effects of the cervical flexion angle during smartphone use on muscle fatigue and pain in the cervical erector spinae and upper trapezius in normal adults in their 20 s. J. Phys. Ther. Sci. 2017, 29, 921-923. [CrossRef] [PubMed]

12. Lee, S.; Kang, H.; Shin, G. Head flexion angle while using a smartphone. Ergonomics 2015, 58, $220-226$. [CrossRef] [PubMed]

13. Lemola, S.; Perkinson-Gloor, N.; Brand, S.; Dewald-Kaufmann, J.F.; Grob, A. Adolescents' electronic media use at night, sleep disturbance, and depressive symptoms in the smartphone age. J. Youth Adolesc. 2015, 44, 405-418. [CrossRef]

14. Hassani, S.; Kelly, E.H.; Smith, J.; Thorpe, S.; Sozzer, F.H.; Atchley, P.; Sullivan, E.; Larson, D.; Vogel, L.C. Preventing distracted driving among college students: Addressing smartphone use. Accid. Anal. Prev. 2017, 99, 297-305. [CrossRef]

15. Klauer, S.G.; Guo, F.; Simons-Morton, B.G.; Ouimet, M.C.; Lee, S.E.; Dingus, T.A. Distracted driving and risk of road crashes among novice and experienced drivers. N. Engl. J. Med. 2014, 370, 54-59. [CrossRef]

16. Stavrinos, D.; Pope, C.N.; Shen, J.; Schwebel, D.C. Distracted Walking, Bicycling, and Driving: Systematic Review and Meta-Analysis of Mobile Technology and Youth Crash Risk. Child Dev. 2017, 89, 118-128. [CrossRef]

17. Bansal, A.; Garg, C.; Pakhare, A.; Gupta, S. Selfies: A boon or bane? J. Fam. Med. Prim. Care 2018, 7, 828-831. [CrossRef] [PubMed]

18. Panova, T.; Carbonell, X. Is smartphone addiction really an addiction? J. Behav. Addict. 2018, 7, $252-259$. [CrossRef]

19. Heo, Y.; Lee, K. Smartphone Addiction and School Life Adjustment Among High School Students: The Mediating Effect of Self-Control. J. Psychosoc. Nurs. Ment. Health Serv. 2018, 56, 28-36. [CrossRef] [PubMed]

20. Kim, E.; Koh, E. Avoidant attachment and smartphone addiction in college students: The mediating effects of anxiety and self-esteem. Comput. Hum. Behav. 2018, 84, 264-271. [CrossRef]

21. Wang, P.; Lei, L.; Wang, X.; Nie, J.; Chu, X.; Jin, S. The exacerbating role of perceived social support and the "buffering" role of depression in the relation between sensation seeking and adolescent smartphone addiction. Personal. Individ. Differ. 2018, 130, 129-134. [CrossRef]

22. Haug, S.; Castro, R.P.; Kwon, M.; Filler, A.; Kowatsch, T.; Schaub, M.P. Smartphone use and smartphone addiction among young people in Switzerland. J. Behav. Addict. 2015, 4, 299-307. [CrossRef] [PubMed]

23. Beland, L.P.; Murphy, R. Ill Communication: Technology, distraction \& student performance. Labour Econ. 2016, 41, 61-76. [CrossRef]

24. Arain, A.A.; Hussain, Z.; Rizvi, W.H.; Vighio, M.S. An analysis of the influence of a mobile learning application on the learning outcomes of higher education students. Univers. Access Inf. Soc. 2018, 17, 325-334. [CrossRef] 
25. Vega, E.S.; Téllez, R.C.; Martínez, C.R. Adicción a Internet en futuros profesores. Un estudio de caso con alumnado universitario. Innoeduca Int. J. Technol. Educ. Innov. 2016, 2, 46-53. [CrossRef]

26. Elhai, J.D.; Levine, J.C.; Dvorak, R.D.; Hall, B.J. Fear of missing out, need for touch, anxiety and depression are related to problematic smartphone use. Comput. Hum. Behav. 2016, 63, 509-516. [CrossRef]

27. Kwon, M.; Lee, J.Y.; Won, W.Y.; Park, J.W.; Min, J.A.; Hahn, C.; Gu, X.; Choi, J.H.; Kim, D.J. Development and Validation of a Smartphone Addiction Scale (SAS). PLoS ONE 2013, 8, e56936. [CrossRef] [PubMed]

28. Kline, P. An Easy Guide to Factor Analysis; Taylor and Francis: Hoboken, NJ, USA, 2014; ISBN 978-1-317-72560-2.

29. Carrizosa, A. Cuándo Una Persona Es Adicta A Internet, Según La Psiquiatría. Available online: https://www.lanacion.com.ar/1821874-cuando-una-persona-es-adicta-a-internet-segun-la-psiquiatria (accessed on 18 November 2018).

30. Castro Mollo, M.; Celis Velásquez, A.; Medina Pflüker, M.C. Uso de internet y niveles de dependencia entre estudiantes de Medicina Humana. Horiz. Méd. 2012, 12, 27-34.

31. García-Oliva, C.; Piqueras, J.A.; Marzo, J.C. Uso problemático de Internet, el móvil y los videojuegos en una muestra de adolescentes alicantinos. Salud Drog. 2017, 17, 189-200. [CrossRef]

32. Puerta Cortés, D.X.; Carbonell Sánchez, X. Uso problemático de Internet en una muestra de estudiantes universitarios colombianos. Av. En Psicol. Latinoam. 2013, 31, 620-631.

33. Tran, B.X.; Mai, H.T.; Nguyen, L.H.; Nguyen, C.T.; Latkin, C.A.; Zhang, M.W.B.; Ho, R.C.M. Vietnamese validation of the short version of Internet Addiction Test. Addict. Behav. Rep. 2017, 6, 45-50. [CrossRef]

34. Muñoz-Dueñas, C.R.; Burgos-Muñoz, S.J.; Novoa-Sandoval, P.; Toro-Huamanchumo, C.J. Adicción a Internet: ¿cuál es la realidad en estudiantes de medicina de Latinoamérica? Educ. Méd. 2017, 18, 222-224. [CrossRef]

35. Velasco, E.; Agheneza, T.; Denecke, K.; Kirchner, G.; Eckmanns, T. Social Media and Internet-Based Data in Global Systems for Public Health Surveillance: A Systematic Review: Social Media and Internet-Based Data for Public Health Surveillance. Milbank Q. 2014, 92, 7-33. [CrossRef]

36. Konan, N.; Durmuş, E.; Türkoğlu, D.; Ağıroğlu Bakır, A. How Is Smartphone Addiction Related to Interaction Anxiety of Prospective Teachers? Educ. Sci. 2018, 8, 186. [CrossRef]

37. Alhassan, A.A.; Alqadhib, E.M.; Taha, N.W.; Alahmari, R.A.; Salam, M.; Almutairi, A.F. The relationship between addiction to smartphone usage and depression among adults: A cross sectional study. BMC Psychiatry 2018, 18. [CrossRef]

38. Ruiz Palmero, J.; Sánchez Rodríguez, J.; Trujillo Torres, J.M. Utilización de Internet y dependencia a teléfonos móviles en adolescentes. Rev. Latinoam. Cienc. Soc. Niñez Juv. 2016, 14, 1357-1369.

39. INE Población que usa Internet (en los últimos tres meses). Tipo de actividades Realizadas Por Internet. Available online: https://www.ine.es/ss/Satellite?L=es_ES\&c=INESeccion_C\&cid=1259925528782\& $\mathrm{p}=1254735110672 \&$ pagename=ProductosYServicios\%2FPYSLayout (accessed on 18 November 2018).

40. Carbonell, X.; Chamarro, A.; Griffiths, M.; Talarn, A. Uso problemático de Internet y móvil en adolescentes y jóvenes españoles. An. Psicol. 2012, 28, 789-796. [CrossRef]

41. de Miguel, C.R. Perfil de uso del teléfono móvil e internet en una muestra de universitarios españoles: ¿Usan o abusan? Bordón Rev. Pedagog. 2016, 68, 131. [CrossRef]

42. del Barrio Fernández, Á.; Ruiz Fernández, I. Los adolescentes y el uso de las redes sociales. Int. J. Dev. Educ. Psychol. Rev. INFAD Psicol. 2016, 3, 571-576. [CrossRef]

43. Muñoz-Rivas, M.J.; Fernández, L.; Gámez-Guadix, M. Analysis of the Indicators of Pathological Internet Use in Spanish University Students. Span. J. Psychol. 2010, 13, 697-707. [CrossRef] [PubMed]

44. de la Villa Moral, M.; Suárez, C. Factores de riesgo en el uso problemático de Internet y del teléfono móvil en adolescentes españoles. Rev. Iberoam. Psicol. Salud 2016, 7, 69-78. [CrossRef]

45. PuroMarketing 3 de Cada 4 Españoles Aseguran Que No Podrían Vivir Sin Móvil. Las Mujeres, Las Más Adictas. Available online: https:/www.puromarketing.com/107/29911/cada-espanoles-aseguran-podrianvivir-sin-movil-mujeres-mas-adictas.html (accessed on 21 November 2018).

(C) 2019 by the authors. Licensee MDPI, Basel, Switzerland. This article is an open access article distributed under the terms and conditions of the Creative Commons Attribution (CC BY) license (http://creativecommons.org/licenses/by/4.0/). 